\title{
JUDICIAL REVIEW OF CROWN CORPORATIONS
}

\author{
BY ALASTAIR R. LUCAS*
}

\begin{abstract}
The author deals with the role of the judiciary in reviewing the actions of crown corporations as distinct from other government departments or agencies. He first considers the general nature of crown corporations. Then he goes on to discuss the extent to which they have been subject to review by the courts traditionally. Finally he examines the effect of the Charter of Rights and Freedoms on this review.
\end{abstract}

\section{INTRODUCTION}

\section{A. CANADIAN CROWN CORPORATIONS}

Crown corporations have recently been the subject of considerable attention by Canadian politicians. These special public corporations have come to symbolize what is perhaps the most visible philosophical difference between the two major federal political parties, namely the degree of direct state economic activity and the corresponding role of the private sector. Hardly a day passes without media reports on Crown corporation excess or inefficiency, discussions of "privatization" of Crown corporations, and lessons to be learned from Prime Minister Thatcher's U.K. state enterprise privatization policies. This in turn has produced a sizeable literature on issues related to Crown corporations, mainly in the fields of economics and political science. However there has been little legal research on problems associated with Crown corporations.

\section{B. CROWN CORPORATIONS AS DECISION-MAKERS}

Legal commentary on Crown corporations has usually centred on modes of creation, Crown immunity, sources of funds, taxation and accountability. ${ }^{1}$ However, little attention has been given to Crown corporations as a species of regulatory decision-makers. Yet important regulatory decisions in a variety of fields are clearly made either directly or indirectly by Crown corporations.

For example, auto insurance corporations and Crown corporation engery utilities in some provinces clearly exercise price-setting functions. Development corporations and even commercial-type Crown corporations, such as Petro-Canada or Air Canada, can structure purchasing decisions according to locational, or Canadian or regional participation criteria. Housing corporations may acquire and manage property with a view to various objectives, including regional development generally and

- Professor and Director of Research, the University of Calgary Faculty of Law.

This article was developed from preliminary work on the legal position of State Petroleum Corporations, carried out under a Social Sciences and Humanities Research Council of Canada leave fellowship. The author gratefully acknowledges the comments and suggestions of Nigel D. Bankes and Gail Starr, both of the University of Calgary Faculty of Law.

1. M.J. Trebilcock and J.R.S. Prichard, "Crown Corporations: The Calculus of Instrument Choice" in J.R.S. Prichard (Ed.,) Crown Corporations in Canada: The Calculus of Instrument Choice 1, 15 (1983). 
public benefits through subsidized accommodation. ${ }^{2}$ It is the ability of Crown corporations to implement, modify or reverse government policy decisions through low-visibility, informal, incremental means, that makes them such attractive public policy instruments. This is particularly true in circumstances where the efficacy of direct regulation may be limited by constitutional constraints or by regulatory constraints on institutional action, such as limits on voting stock that may be held by banks and other financial institutions. ${ }^{3}$

\section{C. "BUSINESS" DECISIONS}

The difficulty of applying a regulatory model with public law duties and corresponding public law rights to Crown corporations is particularly apparent in the case of commercial Crown corporations. These are corporations involved in "commercial" activities, that is, financial, commercial or industrial operations involving dealing in or supplying goods and services to the public. ${ }^{4}$ They are normally required to function without parliamentary appropriations, and thus correspond roughly to the category of "proprietary" Crown corporations that were, prior to recent amendments, defined in the Federal Financial Administration Act. ${ }^{5}$

On the face of their operations, these Crown corporations may be indistinguishable from similar private sector corporations. They may even be established as ordinary joint stock companies. However, their "shareholder" is the government, and they are either, explicitly in their statutes, or at least implicitly, through government control of the general meeting, instruments in some sense of government policy.

They may also, notwithstanding their resemblance to private sector corporations, be formally designated agents of the Crown, so that in law they may be as much emanations of the Crown as departmental or agencytype Crown corporations. They may even be likened to ordinary government departments. Thus, formal legal status clashes directly with commercial reality. This leads to a basic public policy question. Should commercial Crown corporations be accorded the relative freedom of commercial action enjoyed by private sector corporations, while at the same time taking advantage of the shelter from certain of the regulatory requirements imposed on the private sector?

\section{THE FUNCTION AND SCOPE OF JUDICIAL REVIEW}

What is the function and scope of judicial review in relation to Crown corporations? Normally judicial review is considered to be aimed at ensuring procedural fairness and monitoring the scope and (to a limited

2. See Re Webb and Ontario Housing Corporation (1978) 22 O.R. (2d) 257 (C.A.); revg. 18 O.R. (2d) 427 (Div. Ct.).

3. M.J. Trebilcock and J.R.S. Prichard, supra n. 1 at 31-32.

4. C.A. Ashley and R.G.H. Smails, Canadian Crown Corporations: Some Aspects of Their Administration and Control, 126 (1965).

5. Financial Administration Act, R.S.C. 1970, c. F-10, s. 66(1) and Schedule D as am. by S.C. 1984, c. 31 . 
extent) the correctness of the decisions of government agencies and officials that affect citizens. This suggests that the limits of judicial review coincide with the limits of governmental, as opposed to private, action. Thus, the prerogative remedies of certiorari prohibition and mandamus are said to be available only to review "public" decisions based on statutory or prerogative powers. ${ }^{6}$ Judicial Review Procedure Acts are drafted to provide remedies in relation to "statutory powers of decision", ' and judicial review in the Federal Court is limited to orders or decisions of any "federal board, commission or other tribunal."

However there has been some blurring of this remedial line between statutory and private bodies. It has been held that membership decisions of a special act real estate board are subject to certiorari because they are public in the sense that they are matters "in the interests of the community". Also, it should not be forgotten that judicial review of certain decisions of private or "domestic" bodies such as clubs and societies has long been available. ${ }^{10}$ True, remedies may be limited to declaration and injunction, and rights are often said to be based on contract rather than on the public law concept of ultra vires. Yet the objective is the same, namely protection of affected individuals by ensuring that domestic bodies act fairly and do not exceed their legal authority. This suggests that the dominant perspective is that of affectation of private rights, rather than the "public" or "private" nature of the authority. It is this individual rights perspective that has shown the way to judicial development of the procedural fairness doctrine and abandonment of the strict characterization of decision function approach to natural justice rights.

\section{E. PUBLIC DECISIONS}

Crown corporations, and particularly decisions of commercial Crown corporations, have generally been thought to be beyond the reach of judicial review. The exception is Crown corporations that exercise public statutory powers of decision." Thus, in Canada Metal v. Canadian Broadcasting Corporation, ${ }^{12}$ MacKinnon J.A. of the Ontario Court of Appeal considered whether the C.B.C. is a "federal board commission or other tribunal" and consequently subject to judicial review in the Federal

6. D. Jones and A. De Villars, Principles of Administrative Law 363, 364 and f.n. 34, 40; 366 (1985).

7. E.g., Ontario Judicial Review Procedure Act, R.S.O. 1980, c. 224, ss. 1(f) "statutory power of decision", 1(g) "statutory power", and 2 (applications for judicial review).

8. Federal Court Act, R.S.C. 1970, c. 10 (2nd Supp.) s. 2(1)(g); D. Mullan, Administrative Law, para 256 (1979).

9. R. v. Halifax-Dartmouth Real Estate Board, Ex parte Seaside Real Estate Ltd. (1963) 42 D.L.R. (2d) 442 (N.S.S.C.); rev'd. on other grounds (1964) 44 D.L.R. (2d) 248 (N.S.C.A.); Contra, Re McComb and Vancouver Real Estate Board (1960) 32 W.W.R. 385 (B.C.S.C.).

10. Re McComb and Vancouver Real Estate Board, supra n. 9; D. Mullan, Administrative Law, supra n. 8 at para. 154, 198 citing Re Ness and Inc. Canadian Racing Assn's. [1946] O.R. (Ont. C.A.); and Bass v. Pharmaceutical Assn. of B.C. (1965) 51 W.W.R. 441, aff'd.54 W.W.R. 437 (B.C.C.A.); S. Wex, "Natural Justice and Self-Regulating Voluntary Associations" (1972) 18 McGill L.J. 262.

11. See Re Webb and Ontario Housing Corporation supra n. 2.

12. Canada Metal Co. Ltd. v. C.B.C. (No. 2) (1975) 11 O.R. (2d) 167 (Ont. C.A.). 
Court under s. 18 of the Federal Court Act. In comparing the C.B.C., and the Hamilton Harbour Commissioners, ${ }^{13}$ he stated: ${ }^{14}$
The legislation governing the Hamilton Harbour Commissioners makes it clear that they have extensive powers to make administrative orders, such as licensing and regulating other people in the use of the harbour, as well as power to impose penalties upon persons infringing on their governing statute or their by-laws. This, in my view, is completely different from the C.B.C., a corporate entity carrying on the business of broadcasting in this country with none of the attributes of a federal board, commission or tribunal.

The appropriate distinction was stated, though for another purpose, by Estey, J. in Berardinelli v. Ontario Housing Corporation..$^{15}$ With reference to the powers and duties of the Ontario Housing Corporation under s. 6(2) of The Housing Development Act, ${ }^{16}$ he identified: ${ }^{17}$

... two categories, the one being those actions which entail a public aspect or are inherently of a public nature and the other being a category of activities, including managerial, which are more of an internal or operational nature having a predominantly private aspect .

Similarly, in A.-G. Canada v. Lavell, ${ }^{18}$ Laskin, J. doubted that an Indian Band Council is the type of tribunal contemplated by s. 2(g) of the Federal Court Act, and continued:19
A Band Council has some resemblance to the board of directors of a corporation, and if the words of s. 2(g) are taken literally, they are broad enough to embrace boards of directors in respect of powers given to them under such federal statutes as the Bank Act, R.S.C. 1970, c. B-1, as amended, the Canada Corporations Act, R.S.C. 1970, c. C-32, as amended, and the Canadian and British Insurance Companies Act, R.S.C. 1970, c. I-15, as amended. It is to me an open question whether private authorities (if I may so categorize boards of directors of banks and other companies) are contemplated by the Federal Court Act under s. 18 thereof.

The approach appears to be a form of characterization of function. Only "public" as opposed to managerial functions would be subject to judicial review; and, particularly in the case of commercial Crown corporations, clear public functions such as regulatory powers would be difficult to identify. These cases are instructive. However, they establish no test for identification of public functions, and the Federal Court cases are limited to the specific question of the scope of the category of "federal board, commission or other tribunal", in the Federal Court Act.

Until recently, for judicial review on procedural fairness grounds, and for certain prerogative writ remedies to be available, it was necessary that the exercise by a corporation of a particular decision power or function, be characterized "quasi-judicial", as opposed to administrative. Important criteria included whether rights of individuals were affected, whether a "policy" or operational function was involved, and often, whether the form of the decision process approximated the adversarial model. Consequently "business" matters such as leasing public housing units by a Crown housing corporation, would be characterized as administrative and

13. The subject of consideration by the Ontario Court of Appeal in City of Hamilton v. Hamilton Harbour Commissioners [1972] 3 O.R. 61, 27 D.L.R. (3d) 385 (Ont. C.A.).

14. Supra n. 12 at 170-171.

15. Berardinelli v. Ontario Housing Corporation (1978) 90 D.L.R. (3d) 481 (S.C.C.).

16. Housing Development Act, R.S.O. 1970, c. 213.

17. Supra n. 15 at 496.

18. A.-G. Canada v. Lavell [1974] S.C.R. 1349.

19. Id. at 1379 
thus insulated from judicial review. Recent developments suggest however that Crown corporations - even commercial corporations - may have greater exposure to judicial review than was supposed.

One potential significant factor is the Supreme Court of Canada's decision in B.C. Development Corporation v. Karl Friedmann, B.C. Ombudsman..$^{20}$ The case in fact involved a relatively narrow question concerning the scope of the Ombudsman's jurisdiction under the British Columbia Ombudsman Act. However, the issue was whether the Ombudsman's authority extended to actions and decisions of a British Columbia Crown corporation, and this question in turn depended on whether the corporation's activities could be characterized as a "matter of administration" within the terms of the Ombudsman Act. Thus the case arguably has important implications for the scope of judicial review of administrative decisions by Crown corporations.

A second, more general factor, and one that is relevant to the court's approach in the Friedmann Case, is the emergence of the "new natural justice" - the legal doctrine of procedural fairness. Fairness has already been applied by the courts to decisions of Crown corporations."

A third new factor in the vulnerability of Crown corporations to judicial review is the Canadian Charter of Rights and Freedoms. ${ }^{22}$ If the Charter is found to apply to Crown corporations as one area of its application to "government", 23 then judicial review is available to vindicate Charterprotected rights. Among others these include the right to "liberty and security of the person," and "the right not to be deprived thereof except in accordance with the principles of fundamental justice". ${ }^{24}$ Arguably this provides procedural fairness protections for persons affected by certain Crown corporation decisions, or at least confirms and strengthens preCharter administrative law rights. It may also be a substantive basis for striking down decisions as infringements of Charter protected rights and fundamentally unfair. ${ }^{25}$

The remainder of this paper is devoted to review and analysis of these developments - the implications for Crown corporations of first, the Friedmann Case; second, more generally of the doctrine of procedural fairness; and finally, of the Charter of Rights and Freedoms. Brief conclusions are then stated.

\section{TRADITIONAL JUDICIAL REVIEW}

The question to be examined in this section is the scope for judicial review of actions by Crown corporations on traditional administrative law grounds. Particular attention will be given to procedural review on the

20. British Columbia Development Corporation v. Karl Friedmann (Ombudsman) [1985] 1 W.W.R. 193 (S.C.C.); affg. [1982] 5 W.W.R. 563, 38 B.C.L.R. 56 (B.C.C.A.); revg. 34 B.C.L.R. 132, 130 D.L.R. (3d) 565 (B.C.S.C.). [Hereinafter cited as "the Friedmann case".

21. Re Webb and Ontario Housing Corporation supra n. 2.

22. Canadian Charter of Rights and Freedoms, as enacted in Canada Act 1982 (U.K.), c. 11.

23. Id. s. 32.

24. Id. s. 7.

25. Reference Re Section 94(2) of the Motor Vehicle Act (B.C.) [1986] 1 W.W.R. 481, 24 D.L.R. (4th) 536, 63 N.R. 266 (S.C.C.). 
basis of natural justice or procedural fairness principles. The Friedmann case will be considered in this context.

First, it must be noted that in general the scope for judicial review on procedural fairness grounds has clearly advanced beyond decisions characterized as judicial or quasi-judicial. There may yet be some dispute as to whether natural justice and fairness (the "new" natural justice) should be regarded as separate concepts or as part of the same family of procedural fairness rights. ${ }^{26}$ It is clear however that a remedy will no longer be denied merely because the funcation of the body in question would be characterized as administrative, rather than quasi-judicial. ${ }^{27}$ There is still a fundamental duty of fairness, though the content of this duty in relation to the procedural requirements of natural justice that may be derived from the cases, is still not entirely certain. ${ }^{28}$ Consequently even before the Friedmann case, one major hurdle in the way of judicial review of Crown corporation decisions was largely swept away. The rigidity of the doctrine of characterization was tempered by development of the principles of procedural fairness.

\section{A. THE FRIEDMANN CASE}

The case arose out of activities of the British Columbia Development Corporation (B.C.D.C.) a B.C. Crown corporation established under a special Act of the B.C. legislature. ${ }^{29}$ Its objects generally contemplate promoting and assisting economic development in the province. B.C.D.C. embarked, through its subsidiary, on a redevelopment project on the New Westminster waterfront. Certain property purchased for the project, where a new hotel was to be built, was subject to a lease held by a restaurant, the "King Neptune". The lease was to expire in approximately three years, but operators of the restaurant, a long established and popular seafood restaurant, wished to continue operations. They wanted either a renewal of the lease or an opportunity to purchase the restaurant property. Negotiations commenced, with B.C.D.C. expressing a willingness to include the King Neptune somewhere in the redevelopment plan. As talks continued B.C.D.C. recognized, as the Supreme Court later found, a "moral obligation" to take the restaurant's interests into account in its redevelopment scheme..$^{30}$

However, negotiations foundered and no agreement was reached. Six months prior to expiry of the lease, the operators' restaurant wrote to the B.C. Ombudsman and requested an investigation. They complained that they had been lulled into a false sense of security by B.C.D.C.'s subsidiary, that the offers made to them concerning interim relocation were unacceptable, and that generally the negotiations had been in bad faith. A second complaint, filed after B.C.D.C. had initially challenged the Ombudsman's

26. P. Garant, "Fundamental Freedoms and Natural Justice" in Tarnopolsky and Beaudoin (Eds.) Canadian Charter of Rights and Freedoms: Commentary (1982).

27. Nicholson v. Haldimand-Norfolk Bd. of Commrs. of Police [1979] 1 S.C.R. 311; Martineau v. Matsqui Institution Inmate Disciplinary Bd. (No. 1) [1978] I S.C.R. 118; D. Mullan, "Fairness: The New Natural Justice?" (1975) 25 U.T.L.J. 281.

28. D. Jones and A. DeVillars, supra n. 6 at 236.

29. The Development Corporation Act, R.S.B.C., 1979, c. 93, am. S.B.C., 1980, c. 35, s. 5.

30. The Friedmann Case supra n. 20 at 199 (S.C.C.). 
jurisdiction, was in similar terms to the first, but directed against B.C.D.C. The Ombudsman served a demand on B.C.D.C. for production of certain documents. These documents were delivered in a sealed packet, and at the same time judicial review proceedings were launched in the B.C. Supreme Court for an order quashing the direction to produce documents, for a declaration that the ombudsman lacked jurisdiction, and for an interim injunction prohibiting the ombudsman from examining the documents pending a decision of the merits of the application. The latter order was granted ex parte.

McEachern C.J.S.C. who heard the petition, held that the ombudsman lacked jurisdiction under the Ombudsman $\mathrm{Act}^{31}$ to investigate the King Neptune's complaint. ${ }^{32} \mathrm{He}$ considered that the word "administration" in the term "matter of administration", which defined the ombudsman's jurisdiction under the Act, had three possible meanings: (1) non-judicial "adjudication" of rights in the administrative law sense; (2) management procedures by which an organization governs itself and carries out its functions; or (3) a group who have responsibility for certain functions, such as the executive branch of government. Clearly the latter sense is not appropriate. As for number 1, it was held that the decision not to sell or lease the land to the King Neptune could not be characterized as an administrative law-type adjudication. B.C.D.C. had only to consider its best corporate interests. There was no adjudication at all. Nor was its decision a procedure of management or administration. It merely exercised business judgment in a particular transaction. McEachern C.J.S.C. thus concluded that B.C.D.C.s actions did not constitute a "matter of administration" within s. 10 of the Ombudsman Act.

The ombudsman's appeal was allowed by the British Columbia Court of Appeal, and this decision was affirmed by the Supreme Court of Canada. Anderson J.A. for the Court of Appeal majority concluded simply that B.C.D.C's decision not to renew the lease or sell the property and the conduct leading up to it, "clearly involved the exercise of a governmental power relating to "a matter of administration"". ${ }^{33}$ He summarized his reasons for holding that B.C.D.C's decision related to a matter of administration as follows: ${ }^{34}$

(a) The plain and ordinary meaning of the words "matter of administration" is a "matter relating to the carrying out of the executive or management functions of government".

(b) The word "administration", while including factual situations where the government or its agent is required to decide between competing claims, is not limited to such factual situations.

(c) If a matter relates to the carrying out of executive or management functions, it is a "matter of administration" and does not cease to be such a matter merely because the carrying out of such functions requires the exercise of business judgement.

His Lordship elaborated by quoting first, de Smith's Judicial Review of Administrative Action, ${ }^{35}$ and then Halsbury ${ }^{36}$ to support the proposition that "administrative" and "executive" functions are synonymous.

31. Ombudsman Act, R.S.B.C. 1979, c. 306.

32. (1982) 34 B.C.L.R. 132, 130 D.L.R. (3d) 565 (B.C.S.C.).

33. Supra n. 20 at 569 (W.W.R.) (Emphasis added).

34. Id. at 570.

35. S.A. de Smith, Judicial Review of Administrative Action 57, 60 (3d Ed., 1973).

36. 1 Hals (4th) 7, para. 4 "Organs and Functions of Government". 
Thus, the public executive function carried out by B.C.D.C. is implementation of government policy in accordance with the objects stated in the Development Corporation Act. It makes no difference that this function and conduct relates to "business" activities and involves what might be characterized as business judgments. ${ }^{37}$ The bottom line is that these are public functions carried out under statutory authority.

Dickson J. (as he then was) writing for the Supreme Court, framed his judgment carefully in terms of the specific jurisdictional requirements of the Ombudsman Act. He asked: ${ }^{38}$ (1) whether there was a decision or recommendation made; an act done or omitted; or a procedure used, by B.C.D.C. and its subsidiary; (2) whether B.C.D.C. is an "authority" as described in the schedule to the Act; (3) whether the King Neptune is a "person aggrieved" by this conduct; and (4) whether the complaint was with respect to a "matter of administration".

There was little difficulty in finding B.C.D.C. to be an "authority" since that term was defined to include corporations and other agencies, (a) a majority of the management or directors of which are appointed by statute, by a minister or by Cabinet, (b) are in the discharge of their duties public officers or servants of the province, or (c) are "responsible" to the province.$^{39}$ B.C.D.C. clearly fits this category because its directors are appointed by Cabinet under the Development Corporation Act. ${ }^{40}$ It might have been added, as Anderson J.A. noted in the Court of Appeal, ${ }^{41}$ that B.C.D.C. is expressly made an agent of the Crown.

With respect to a "matter of administration", Dickson J. too quoted de Smith and Halsbury to link the terms "administrative" and "executive", and to confirm that in administrative law this includes application of general rules or policy to particular cases in accordance with the requirements of policy or administrative practice. This, Dickson J. affirmed, does not exclude governmental conduct in the proprietary or business sphere. The essence of administrative action is simply the application of general public policy in particular situations.$^{42} \mathrm{He}$ concluded that: ${ }^{43}$

\footnotetext{
A transaction can thus be characterized as a matter of administration even though it carries a business flavour. Indeed, a bewildering array of government authorities now regularly implement governmental policies and programs in the marketplace. The decisions made by the government's agents in these areas are no less administrative merely because the policies they implement are tied to some greater or lesser extent to business concerns.
}

Finally, he made it clear that he was not simply characterizing the B.C.D.C. activity in question as implementation of government policy, as opposed to carrying on a commercial enterprise. Anderson, J.A. in the Court of Appeal appeared to make this kind of distinction. Dickson, J. disagreed and concluded that B.C.D.C. engaged in both a commercial

37. Supra n. 20 at $572-573$ (B.C.C.A.).

38. Supra n. 20 at 208 (S.C.C.).

39. Supra n. 20 at 209.

40. Development Corporation Act, R.S.B.C. 1979, c. 93, (am. 1980, c. 35, s. 5), s. 7, Schedule, Item 2(c).

41. Supra n. 20 at 572 (B.C.C.A.).

42. Supra n. 20 at 214.

43. Id. 
enterprise and a program to implement government policy.4 This fact in itself does not make its action any less a "matter of administration".

The narrow principle of the Friedmann case may be limited to the meaning of the particular provision in the B.C. Ombudsman Act. At its widest the case may be considered to establish principles for determination of the scope of authority of ombudsmen in relation to "quasi-public" bodies such as Crown corporations.

Mr. Justice Dickson was careful to point out that the ombudsman exercises limited powers. These are confined to investigation, recommendation and publicity. ${ }^{45}$ There is no binding authority, no power to overrule the decisions of government officials, so that the ombudsman cannot impede the functions of agencies and officials with which he deals. Arguably the case concerns only a very special and limited form of power to intervene in public decisions. Presumably this is why the court carefully considered and analyzed the institution of ombudsman, but gave little or no attention to the legal and institutional character of Crown corporations. It was enough to find that B.C.D.C. is a public authority.

However, it is significant that the court's analysis of the legal position of B.C.D.C. in relation to the investigative powers of the ombudsman was cast in administrative law terms. Both Dickson J. and the Court of Appeal majority asked whether "administration" in the Ombudsman Act carried the same meaning as "administrative" or "executive" in the law of judicial review of administrative action, and both answered this question in the affirmative. Both courts then considered whether the B.C.D.C. actions and decisions in relation to the renewal of the lease or sale of the property should be considered "administrative" in this sense. Again both answered in the affirmative, and the reason was simple and basic - B.C.D.C. is a public body, established by statute, controlled by government, and making decisions on matters of government policy. The fact that these decisions may resemble, or in fact be precisely similar to actions of private corporations in the course of business, was considered to be of no importance.

There was no attempt by Dickson $J$. to qualify his opinion by underlining limitations on the scope of judicial review in relation to Crown corporations such as B.C.D.C. Indeed, the unqualified use of judicial review terminology suggests an intention to raise the tantalizing question of the scope of judicial review in this context. It is not a "hunting licence", but merely a scholar's flag indicating a fruitful area for future exploration.

\section{B. FAIRNESS - THE WEBB CASE}

This view of Crown corporation actions is consistent with that taken by the Ontario Court of Appeal of another Crown corporation development authority - the Ontario Housing Corporation. In Re Webb and Ontario Housing Corporation, ${ }^{45}$ Webb, a tenant of a subsidized apartment in one of the Corporation's buildings was, after repeated warnings about the

44. Id. at 216.

45. Id.

46. Supra n. 2. 
behaviour of her children, given notice to vacate. The action was taken by O.H.C's management contractor and was approved by the Corporation's Board of Directors. Judicial review was sought either under or apart from the Statutory Powers Procedure Act ${ }^{47}$ on the ground that Webb had been denied a hearing contrary to the principles of natural justice or procedural fairness.

The application for judicial review was refused by the Divisional Court. ${ }^{48}$ On appeal, the Court of Appeal held that there was no right to judicial review under the Statutory Powers Procedure Act. The court, in its unanimous opinion reviewed O.H.C's statutory powers and quoted ${ }^{49}$ Estey J's distinction between "public" powers and "private and operational" functions from the Berardinelli case. ${ }^{\text {so }}$ According to Estey J., this latter category would include the "more mundane functions of management in its every detail, including the removal of garbage, cleaning of windows, letting and reletting of units becoming vacant ... and numerous other aspects of management". .1

MacKinnon, A.C.J.O. concluded that: ${ }^{: 2}$

Although there is a public aspect to this matter which 1 have noted and to which I shall refer later, the decision taken is only part of the administrative duties imposed on O.H.C. There is no judicial or quasi-judicial quality to its action in this regard. Courts must be careful not to "judicialize" every administrative act of every incorporated body (which has its powers by virtue of a statute) or life in this Province will come to a standstill.

Consequently the Corporation's Board of Directors did not exercise a statutory power of decision conferred by an Act of the Legislature for which is was "required by or under such Act or otherwise by law to hold or to afford to the parties to the proceedings an opportunity for a hearing before making a decision". ${ }^{33}$ From this point it was easy to also conclude that there was no quasi-judicial function that required application of the audi alteram partem principle. ${ }^{54}$

The matter did not end there. It was still necessary to consider whether the fairness doctrine applied and if so whether or not the Corporation had acted fairly. MacKinnon, A.C.J.O. stated that: ${ }^{\text {ss }}$

There surely can be actions which are neutral and which require no procedures to which the designation "fair" or "unfair" need to be attached, where, in the exercise of a public corporation's rights or in carrying out its obligations, the interests of others might be, quite properly, affected. The Courts are, however, increasingly applying the test of proceudral "fairness" to administrative actions of donees of a power and there is, understandably and naturally, a predilection towards seeing that everyone is treated fairly.

The conclusion was that the fairness doctrine did apply. While the Corporation's decision was "administrative" in traditional administrative

47. Statutory Powers Procedure Act, R.S.O. 1980, c. 484.

48. (1978) 18 O.R. (2d) 427 (Div. Ct.).

49. Supra n. 2 at 260.

50. Berardinelli v. Ontario Housing Corporation supra n. 15, at 496.

51. Id.

52. Supran. 2 at $260-261$.

53. Statutory Powers Procedure Act supra n. 47, s. 3.

54. Supra n. 2 at 261.

55. Id. 
law parlance, nevertheless a substantial right was at stake since Webb had the "very real benefit of a reduced and subsidized rent". .6

\section{LEGITIMATE EXPECTATIONS}

There is also authority to suggest that procedural fairness rights may be available where legitimate expectations, such as routine renewal of licences, are affected. ${ }^{57}$ Also relevant are cases in which more conventional administrative decisions have been set aside on procedural fairness grounds where informal rules or policy directions have raised legitimate expectations in affected parties. Where such informal rules turn out to be misleading, to the detriment of persons affected, a remedy will be avilable. ${ }^{88}$ The significance of such legitimate expectations in relation to particular Crown corporation decisions is likely to be a major determinant of whether judicial review based on procedural fairness is available.

\section{CONCLUSIONS ON CONVENTIONAL JUDICIAL REVIEW}

The implications of these decisions for Crown corporations, even commercial Crown corporations that pursue profit objectives and compete in the private sector, may be significant. The Friedmann case suggests that the mere fact that these Crown corporations are established and controlled by government and can be said to make decisions to further public policies, may make a wide range of their actions, including actions that might otherwise be characterized as business decisions, subject to judicial review. This would, as the $W e b b$ case suggests, invoke the requirements of procedural fairness and may also bring in the various scope and correctness grounds for review.

However, not all Crown corporation actions can be characterized as administrative in the sense of the Friedmann and Webb cases. Dickson, J. in Friedmann stated that " 'a matter of administration' encompasses everything done by governmental authorities in the implementation of government policy" ${ }^{39}$ This leaves room for application of functional tests to determine whether a particular commercial Crown corporation is a "governmental authority"; although the widespread use of statutory declarations of Crown agency may limit this approach..$^{60}$

We are led to consider the meaning of the term "governmental policy". It may be possible to distinguish major decisions by Crown corporations that can be linked to government policies, and lesser actions that occur in the day-to-day affairs of the corporation. For example, Petro-Canada's negotiations with private joint owners following assignment to it of a Crown share interest under the Canada Oil and Gas Act ${ }^{61}$ may be in

56. Id. at 265.

57. See McInnes v. Onslow-Fane [1978] 1 W.L.R. 1520 (Ch.D.).

58. See R. v. Sec. of State for the Home Department, Ex parte Khan [1985] 1 All E.R. 40 (C.A.).

59. Supra n. 20 at 216.

60. S. 105 of the Financial Administration Act, R.S.C. 1970, c. F-10, added S.C. 1983-84, c. 31, s. 11, provides that "agent corporations", defined (s. 95) as Crown corporations that are expressly declared by any other Act of Parliament to be agents of the Crown, may exercise their powers only as agents of the Crown.

61. Canada Oil and Gas Act, S.C. 1980-81-82-83, c. 81, ss. 30, 61, 63. This system is scheduled to be replaced by the Canada Petroleum Resources Act, Bill C-92, 1985. 
pursuance of the government policies of increasing Canadian ownership and control in the oil and gas industry, as well as direct government participation in Canada Lands oil and gas exploration. Actions and decisions in this context may be subject to judicial review. On the other hand, negotiation by Petro-Canada with a service station lessee, may not be reviewable because it cannot be clearly linked to any articulated government policy.

The concept of procedural fairness may prove particularly difficult for Crown corporations to shake. In the example above, given a public corporation and actions by the corporation that affect the rights or property of persons, it is difficult to see why oil and gas companies, but not individual service station lessees, should be entitled to procedural fairness protection in dealings with the corporation. Yet this may be precisely the result of application of the public function/private operational function distinction from the Berardinelli ${ }^{62}$ case. On the other hand, the $W e b b^{63}$ case makes it clear that courts will continue to be vigilant where matters of private entitlement to social benefits arise in relation to Crown corporations.

This leads to the conclusion that the test for an application of conventional judicial review principles is not likely to be limited to government function with focus on the Crown corporation and its action. Rather it will be a kind of sliding scale that also takes into account effect of the Crown corporation's action on private rights, and the nature of the rights affected. Even in the case of "business decisions" (such as a service station lease by Petro-Canada), public elements arising from the corporation's consumer protection and security of supply objectives can be identified. Significant private rights, or at least legitimate expectations, are involved, particularly in the case of negotiations for renewal of the service station lease. There is also a discernible public interest in the protection of individual franchise holders from predatory practices of powerful franchisor corporations. This may be sufficient basis for at least minimal procedural fairness protection that may include no more than good faith and clarity of communication in the negotiation process.

\section{THE CHARTER OF RIGHTS AND FREEDOMS}

The basis for judicial review of "administrative" decisions of Crown corporations may be significantly broadened by the Canadian Charter of Rights and Freedoms. In particular, section 7 provides that:

7. Everyone has the right to life, liberty, and security of the person and the right not to be deprived thereof except in accordance with the principles of fundamental justice.

Thus, taking the example of the Friedmann case, the operators of the King Neptune restaurant may be in a position to argue that their "security of the person" in the sense of security in the on-going operation of their establishment, was violated by the B.C.D.C. method of negotiation and decision. Taking a minimalist view of Charter intervention, there may be a procedural right to treatment according to the principles of fundamental justice, which must at least encompass the doctrine of procedural

62. Supran. 15.

63. Supra n. 2. 
fairness. ${ }^{64}$ Moving to the other end of the protected rights continuum, there may be a substantive right to liberty or security of the person that would preclude deprivation of livelihood as a result of the actions and decision of the Crown corporation. ${ }^{65}$ This argument is most strongly put in terms of deprivation of a personal, though perhaps essentially economic right, rather than as the taking of some form of property, since the history of Charter negotiations suggest a relatively clear intention to exclude protection against the taking of traditional property rights. ${ }^{60}$

Section 15 , the equality rights provision, may also be relevant. Again, using the Friedmann case example, the argument for the restaurant operators would be that there was a denial of equal protection and equal benefit of the law in its negotiations with B.C.D.C. Given the government authority-character of B.C.D.C., the restauranteurs are entitled to procedural fairness in the negotiations and to be placed, in relation to the decision, on an equal footing with persons who are affected by the actions of other public officers and public bodies. In other words, equal protection requires the benefit of at least procedural fairness protections, including good faith in consultation and consideration of offers, clarity in communications, and reasonable dispatch in the negotiations.

Similarly it may be argued that section 15 , and possibly section 7 , prevent Crown corporations from asserting immunity based on Crown agency status against affected persons. ${ }^{67}$ More straightforward equality rights such as freedom from discrimination in employment decisions on the basis of age, sex, etc., may also be asserted against Crown corporations. It is also possible to imagine circumstances in which other Charter rights and freedoms including religion, association, and expression may be protected against Crown corporation actions.

These potential Charter-based grounds for judicial review of Crown corporations will be discussed in more detail. First, however, it is necessary to consider whether the Charter applies to Crown corporations in the first instance.

\section{A. APPLICATION TO CROWN CORPORATIONS}

The majority of commentators have expressed the view that the Charter does not apply to private conduct, whether individual or corporate. ${ }^{68}$ This is based largely on the specific references to the "government" of Canada and to the "government" of each province in s. 32(1). Clearly, Charter application goes beyond "laws" in the sense of statutes and regulations. It appears to include the common law, ${ }^{69}$ and to extend to all manner of government decisions including specific statutory decisions, and policy

64. See Singh v. Minister of Manpower and Immigration (1985) 58 N.R. 1 per Wilson J. at 62.

65. T. Christian, "Section 7 of the Charter of Rights and Freedoms: Constraints on State Action" (1984) 22 Alta. L. Rev. 222, 240-241.

66. See J. Whyte, "Fundamental Justice" (1983) 13 Man. L.J. 455.

67. See infra p. 32.

68. P. Hogg, Constitutional Law of Canada 674 (2nd Ed., 1985); K. Swinton, "Application of the Canadian Charter of Rights and Freedoms", in Tarnopolsky and Beaudoin, supra n. 26, ch. 3.

69. D. Gibson, The Law of the Charter: General Principles (1986) 99; Operation Dismantle v. The Queen (1985) 18 D.L.R. (4th) 481 at 494 dictum per Dickson, J. 
formulations by government officials, ${ }^{70}$ by regulatory agencies ${ }^{11}$ and even by the cabinet. ${ }^{2}$ The terms of s. 32, it is argued, make it clear that actions of a non-governmental character are outside the scope of the Charter. However, some apparently private actions such as an arrest by private security personnel, may be subject to the Charter because they involve an established public responsibility. ${ }^{73}$

Thus commentators have asserted that the Charter does not apply to all Crown corporations or to all functions of particular Crown corporations. ${ }^{74}$ This is based on the application of some form of "government function" test drawn from $\mathbf{s} .32^{75}$ but influenced substantially by the United States "state action" doctrine. The American approach essentially involves asking whether or not the action in question relates more closely to state or to private interests and functions. ${ }^{76}$

Crown agency is taken as the starting point. All Crown corporations that are agents of the Crown either on the basis of the common law tests ${ }^{n}$ or as a result of an express statutory declaration of Crown agency, woud be subject to the Charter. ${ }^{78}$ There are, however, certain recognized exceptions to the general Crown immunity principle, so that the doctrine has been characterized as one of "relative or restrictive sovereign immunity"..

As Swinton points out ${ }^{80}$ this Crown agency approach immediately poses problems, since a range of considerations may underlie government decisions to make Crown corporations agents of the Crown or not. For

70. Southam Inc. v. Hunter [1984] 2 S.C.R. 145, 55 N.R. 241, 33 Alta. L.R. (2d) 193 (S.C.C.) (Director of Investigation and Research, Combines Investigation Branch).

71. Singh v. Minister of Manpower and Immigration supra n. 64 (Immigration Appeal Board); Hunter v. Southam Inc. supra n. 70 (Restrictive Trade Practices Commission).

72. Operation Dismantle Inc. v. The Queen in Right of Canada (1985) 18 D.L.R. (4th) 481 (S.C.C.), (Federal Cabinet).

73. R. v. Lerke [1986] 3 W.W.R. 17, 25 D.L.R. (4th) 403 (Alta. C.A.). (Tavern employees searching patron and seizing drugs characterized as citizen's arrest - a public function in the context of the criminal justice system.).

74. K. Swinton, supra n. 68 at 57; P. Hogg, supra n. 68 at 672.

75. K. Swinton, id. The Alberta Court of Appeal in R. v. Lerke supra n. 73 used, but did not define, the term "governmental function". Laycraft, C.J.A.s judgment suggests that his test for a governmental function was based on whether or not historical evidence showed the development and existence of rights or duties intended to carry out some public purpose (p. 409-410 (D.L.R.)).

76. This is a generalization. The area is a complex and confusing one in which no general theory appears to have emerged. See Gibson, supra n. 69 at 89-90.

77. See Bombay Province v. Bombay Municipal Corp. [1947] A.C. 58 (P.C.); R. v. Eldorado Nuclear Ltd. [1983] 2 S.C.R. 551, 50 N.R. 120; Sparling v. Caisse de Dépót et Placement du Quebec (1985) 29 D.L.R. 259 (Que. C.A.).

78. P. Hogg, supra n. 68.

79. Sparling v. Caisse de Dépót et Placement du Quebec supra n. 77. The court considered four exceptions, i.e.,

(1) "Necessary implication" - a statute applies to a Crown agent if non-application would cause the statutory purpose to be "wholly frustrated";

(2) "Crown Commercial" - a statute applies to a Crown agent's public or political acts as opposed to its management activities;

(3) "Contract Theory" - a Crown agent is bound by a contract with a subject under the law governing the contract;

(4) "Law invoked by the Crown" - a Crown agent is bound by relevant statutes where it invokes a particular law as a basis for assertion of rights.

80. Supra n. 68 at 58. 
example, corporations that arguably exercise significant government policy and even decision-making authority, such as Air Canada, may not be designated Crown agents in order to preserve their formal commercial independence. In other cases, Crown agency may be used to confer particular tax or regulatory immunity. ${ }^{81}$ Sometimes, Crown agency may be more a consequence of draftsman's boiler plate than anything else. Swinton also notes correctly, ${ }^{82}$ that the common law Crown agency principles developed more as a result of vicarious liability considerations than with a view to governmental function.

Gibson $^{83}$ has suggested that as a matter of interpretation, the term "government" in s. 32, should be taken to have been used with the intention of rebutting the interpretive presumption that statutes do not apply to the Crown without explicit reference ${ }^{84}$ or necessary implication. Crown corporations that are agents of the Crown have been held to be immune from statutes that do not, by explicit reference or by clear implication, bind the Crown.

This was the result in The Queen v. Eldorado Nuclear Ltd. ${ }^{85}$ in which the Supreme Court held that the Combines Investigation $\mathrm{Act}^{86}$ does not apply to the Crown corporations Eldorado Nuclear Ltd. and Uranium Canada Ltd. Since none of the recognized Crown immunity exceptions appeared to apply, the decision followed almost automatically from the finding that both corporations are agents of the Crown. In fact, this case, at least for a time, proved to be something of a cause celebre at a time when there was much public debate about "big government" following implementation of the National Energy Program and during discussion leading to development of the Charter of Rights and Freedoms. This suggests that if Gibson ${ }^{87}$ is correct in his interpretation of s. 32, the Charter draftsmen are not likely to have been unaware of the legal position of Crown corporations when writing s. 32. The effect of the Charter on institutions of government, including Crown corporations, could not have been far from the minds of the legislators.

However, a conclusion that, as a matter of purposive constitutional interpretation, the Charter may apply to Crown corporations is merely the first step. Otherwise one is left with the uncomfortable conclusion that even commercial Crown corporations are subject to the Charter in all of their business activities. Actions and decisions essentially indistinguishable from private actions would thus be within the purview of the Charter. Moreover, Crown corporations' actions that are not directly authorized by

81. Id.

82. Id.

83. D. Gibson, "The Charter of Rights and The Private Sector" (1982) 12 Man. L.J. 213.

84. Id. at 214.

85. The Queen v. Eldorado Nuclear Limited supra n. 77.

86. Combines Investigation Act, R.S.C. 1970 c. C-23; am. and renamed, The Competition Act, by S.C. 1984-85-86, c. 91, Part II. The latter added s. 2.1 which provides that the Act is binding and applies to an agent of the federal or provincial Crown that is a corporation,

“. . . in respect of commercial activities engaged in by the corporation in competition, whether actual or potential, with other persons to the extent that it would apply if the agent were not an agent of her Majesty."

87. D. Gibson, supra n. 83. 
any special legislation, but rather flow from powers acquired under capacity conferred by the creating legislation would also be included if this blanket approach is taken..$^{88}$

Any attempt to avoid this result immediately highlights the difficulties with. "government function" tests. A distinction between public or governmental activities and commercial activities is very difficult to apply in practice. As Gibson ${ }^{89}$ points out, even such factors as profit-making and the presence or absence of competition, may not be reliable guides to whether actions of Crown corporations are governmental or essentially those of private commercial operations. This is particularly so in the case of corporations whose activities parallel those of private sector corporations, but which may have sophisticated public objectives, such as providing information on the operation of a particular regulated private sector.

In the area of sovereign immunity the courts have already developed some experience on the very closely related matter of distinguishing actions of the "Crown Commercial" ("jure gestionis") and the Crown acting "jure imperii" for public purposes. The approach suggested by cases such as Hydro Que. v. Churchill Falls (Labrador) Corp.,$^{90}$ and Sparling v. Caisse de Dépôt ${ }^{\text {श1 }}$ is to examine the statutory purposes and objects of the Crown corporation, along with its actions in the circumstances, to determine the degree of relationship to public purposes as expressed by legislation or government policy declarations. A relatively low degree of relationship may suffice to establish public purposes. In the Sparling case, for example, the Caisse de Dépôt management of funds received by the Quebec government for such purposes as pension plans, workers' compensation and health insurance, was held to be a public and not merely a commercial purpose. Notwithstanding that its functions were essentially banking activities (given the alternative of investing the funds through private institutions), the court chose to identify the government's alternative as financial management by other government departments or agencies ${ }^{22}$ with the possibility that the money would be "left to lie idle".

However this relative sovereign immunity approach is one-dimensional, focussing almost completely on the powers and actions of the Crown corporation. The need for a qualitative standard, related more closely to particular actions and to the scope and objective of particular Charter rights and guarantees, is apparent. Gibson ${ }^{93}$ recommends a version of the technique urged on U.S. courts by Professor Tribe. This involves a case by case approach in which the court considers first, the nature and extent of government involvement in the subject action, and second, whether the

88. D. Gibson, supra n. 69 at 105, citing Bonanza Creek Mining Co. v. R. [1916] A.C. 566 (P.C.).

89. D. Gibson, "Distinguishing the Governors from the Governed" (1983) 13 Man. L.J. 505, 517, D. Gibson, supra n. 69 at 101.

90. Commission Hydroelectrique du Quebec v. Churchill Falls (Labrador) Corp. [1980] C.A. 203 (Que. C.A.); Rev'd., [1982] 2 S.C.R. 79, 137 D.L.R. (3d) 577 (S.C.C.).

91. Sparling v. Caisse de Dépót et Placement du Quebec, supra n. 77.

92. Id. at 278.

93. D. Gibson, "Distinguishing the Governors from the Governed: The Meaning of 'Government' Under Section 32(1) of the Charter" supra n. 89 at 518. 
particular guaranteed right or freedom alleged to have been infringed will be significantly eroded or qualified if it is not held to apply to the Crown corporation action in question..$^{94}$

Thus, if a federal Crown energy corporation decided to establish facilities for storage of hazardous waste in a particular community, a court may be called upon to consider whether the rights of residents to "life, liberty and security of the person" would be significantly affected if the Charter were construed not to apply. Similarly, if a Crown corporation continued to impose mandatory retirement on its employees contrary to Charter rights to equality, ${ }^{95}$ would the anomaly of the Crown corporation not being bound by the Charter significantly erode the right to equality? One relevant factor might be whether other appropriate non-Charter remedies are available. Another factor might be the relative number of employees affected in the particular sector and in the Canadian workforce generally. Whether or not analogous human rights code infringements had been found and remedied in the case of private corporations may also be relevant. All of these questions would bear on the issue of whether the fundamental age discrimination protection for employees would be significantly weakened if it is not applied to Crown corporations.

\section{B. BASIS FOR REVIEW}

\section{Section 7}

The Charter right that seems most relevant to protection of individuals against actions or decisions of public bodies such as Crown corporations is that in s. 7 concerning "life, liberty and security of the person". The latter elements of this right - liberty and security of the person - appear promising. Both, particularly "liberty", in view of the U.S. approach, could be invoked in relation to statutory entitlements or benefits administered by Crown corporations. ${ }^{96}$ It is more difficult to imagine examples of "life", being infringed, though this is not entirely impossible. Consider, for example, actions by Atomic Energy Canada Ltd. concerning nuclear reactor construction and operation, transportation and handling of radioactive products, and disposal of radio-active waste. Given the serious health dangers posed by radioactive isotopes, it is quite possible that decisions in these areas may be found to affect individuals' rights to "life" as well as "security of the person". 9 "

94. Gibson's formulation of Tribe's approach is actually framed positively: would application of the particular Charter protected right to the Crown corporation action "advance the value served" by that right? See id; Gibson, supra n. 69 at 91 .

95. On the assumption that this right will ultimately be upheld by the courts. Compare Harrison v. University of B.C. (1986) 8 C.R.D. 350.10-07 (B.C.S.C., July 23, 1986, Taylor J.) (Mandatory retirement at age 65 for a tenured professor and a senior administrator required by a public university held not to contravene s. 15(i); nor does B.C. Human Rights Act definition of "age" as from 45 years or more to less than 65 years, contravene s. 15), and Stoffman v. Vancouver General Hospital (1986) 8 C.R.D. 350.10-09 (B.C.S.C. July 23, 1986, Taylor J.) (Regulation of a public hospital withdrawing doctor's admitting privileges at age 65 held to contravene s. 15(1)).

96. Like the subsidized public housing in the Webb case. See L. Tribe, American Constitutional Law 515 (1978).

97. See Operation Dismantle Inc. v. The Queen supra n. 72. 
The scope of the s. 7 rights is by no means clear. However, preliminary judicial indications are that several specific rights that are highly relevant to review of Crown corporation actions may not be included in s. 7. One is the right to the enjoyment of property. An amendment proposed by the Progressive Conservative Party that would have inserted the phrase "enjoyment of property" into s. 7, was debated and eventually rejected by the Special Joint Committee of the House of Commons and the Senate on the Constitution. ${ }^{98}$ It has nevertheless been argued, ${ }^{99}$ and accepted by the New Brunswick Court of Queen's Bench in The Queen v. Fisherman's Wharf Ltd. ${ }^{100}$ that "security of the person" can include the right to carry on business, which encompasses the holding of property. Indeed property holding and dealing may be the principal purpose of the business. ${ }^{101}$ On the other hand, the Alberta court has held that an owner of expropriated property is not entitled to $\mathrm{s.} 7$ protection. ${ }^{102}$

While it has been convincingly argued that security of the person includes a person's capacity to meet basic human needs through economic means, ${ }^{103}$ it seems unlikely in view of the clear and deliberate omission of the term "property", that full property rights protection can be read into s. 7. ${ }^{104}$ The Fisherman's Wharf case was affirmed on non-Charter grounds. But La Forest J.A., of the New Brunswick Court of Appeal, stated that security of property was not expressly protected by the Charter in order to "avoid frustration of regulatory schemes intended to reallocate rights and resources." ${ }^{105}$ Crown corporations are often major direct or indirect instruments for precisely this kind of reallocation.

Such property rights protection would also depend upon $\mathrm{s} .7$ protection being held to be substantive, and not merely procedural compliance with the "principles of fundamental justice". The substantive effect of $s .7$ has now been confirmed by the Supreme Court of Canada in Reference Re S. 94(2) of the Motor Vehicle Act. ${ }^{106}$

Lower court decisions indicate strong judicial resistance to protection of economic rights in the nature of valuable regulatory benefits or "new property" "ights. This includes a commercial public service certificate

98. Special Joint Committee of the Senate and of the House of Commons of the Constitution of Canada, 1980-81, Minutes of Proceedings January 27, 1981, 46:3-46:4; Proceedings, January 26, 1981, 45:10-45:12.

99. J. White, supra n. 66 .

100. The Queen in Right of New Brunswick v. Fisherman's Wharf Ltd. (1982) 135 D.L.R. (3d) 307 (N.S.Q.B.).

101. This approach has been critized by G. Brand in "Canadian Charter of Rights and Freedoms - Right to Property as an Extension of Personal Security - Status of Undeclared Rights" (1983) 61 Can. Bar Rev. 398; and by P. Hogg in Constitutional Law of Canada supra $\mathrm{n} .68$ at 745-6.

102. Re Becker and The Queen in right of Alberta (1983) 148 D.L.R. (3d) 539 (Alta. C.A.). Semble, Re Workers' Compensation Board of Nova Scotia and Costal Rentals, Sales and Service Ltd. (1983) 12 D.L.R. (4th) 564 (N.S.S.C.); Manicom v. County of Oxford (1985) 21 D.L.R. (4th) 611 (Ont. Div. Ct.).

103. J. Whyte, supra n. 66.

104. P. Hogg, supra n. 68 at 745.

105. (1982) 44 M.P.R. (2d) 201,204 (N.B.C.A.).

106. Reference Res. 94(2) of the Motor Vehicle Act supra n. 25.

107. Charles Reich, "The New Property" (1964) 73 Yale L.J. 733; T. Lee, "Section 7: an Overview" (1985) 43 U. of T. Fac. L. Rev. 1, 6-7. 
issued by a Motor Transport Board, ${ }^{108}$ a taxi licence, ${ }^{109}$ and expectations of hearing costs by consumer intervenors in a Public Utilities Board rate proceeding ${ }^{110}$ and of a discretionary government grant by an oil and gas company. "' However, refusal by a municipality to grant a business licence has been held to constitute deprivation of liberty under s. 7.12

Another important right in this context that lower courts have so far declined to bring within s. 7 protection is freedom of contract. Notwithstanding U.S. jurisprudence in which the term "liberty" in the Fifth and Fourteenth Amendments has been held to include a right to privacy and to the absence of unreasonable restraint upon individuals in the conduct of business and the use of equipment or property, ${ }^{113}$ the Federal Court of Canada has held that life, liberty and security of the person does not include freedom of contract. ${ }^{114}$ In the Friedmann case, ${ }^{115}$ this is clearly a right that the operators of the King Neptune restaurant would wish to assert against the B.C. Development Corporation.

\section{Section 15}

The section 15 grounds of discrimination have relatively little special judicial review significance for Crown corporations. There is, of course, the possibility of such issues as discrimination in employment on these or other named grounds. However, it is difficult to see that the issues related to section 15 rights infringement would be much different than in the case of discrimination by more conventional government agencies or officials. There may, however, be shades of distinction when state objectives are identified and weighed, at the section 1 balancing stage of analysis, since questions of the relative public advantages of state enterprise may arise. Yet this analysis will still be merely a variation of the basic rationality and proportionality themes that the Supreme Court has already identified as the appropriate approach to section 1 analysis. ${ }^{116}$

Despite lack of judicial clarity in many of the early s. 15 decisions, the scheme of the Charter appears to contemplate that the question of whether any particular distinction is justified or not, should be made under $\mathrm{s} .1$, rather than through definition of the scope of the protected right under $s$.

108. Gershman Produce Co. Ltd. v. Manitoba Motor Transport Board (1985) 16 Admin. L.R. 1 (Man. C.A.).

109. Re Abbotsford Taxi Ltd. and B.C. Motor Carrier Commission (1985) 23 D.L.R. (4th) 365 (B.C.S.C.).

110. Manitoba Society of Seniors v. Greater Winnipeg Gas Co. (1982) 18 Man. R. (2d) 440 (Man. C.A.).

111. Re Regal Petroleum Ltd. and Minister of Energy Mines and Resources (1985) 63 N.R. 135 (F.C.A.).

112. Re D\& H Holdings Ltd. and City of Vancouver (1985) 21 D.L.R. (4th) 230 (B.C.S.C.).

113. T. Christian, supra n. 65 at 232-33.

114. Re Groupe des Eleveurs des Volailles De l'Est de l'Ontario and Canadian Chicken Marketing Agency (1984) 14 D.L.R. (4th) 151 (F.C.T.D.); Public Service Alliance of Canada v. The Queen in Right of Canada (1984) 11 D.L.R. (4th) 337 (F.C.T.D).

115. Supra n. 20.

116. See R. v. Oakes (1986) 65 N.R. 87 (S.C.C.). 
15. ${ }^{117}$ This is consistent with the two stage approach to Charter analysis that has been approved for other rights including legal rights and the s. 2 fundamental freedoms. ${ }^{118}$ Certainly this is likely to be the case where one of the enumerated grounds of discrimination is asserted.

It is plain, however, that the named grounds of discrimination are not intended to be exhaustive. They are examples only, leaving an open-ended "other grounds" category for judicial definition. ${ }^{119}$ One ground already suggested as potentially arguable by the restauranteurs in the Friedmann case comes down to discrimination on the basis of "business position" in the sense of necessity to deal with a particular party, namely the Crown corporation, as opposed to a private corporation engaged in the same line of business. If the Crown corporation is in a position to shelter behind the sovereign immunity principle, or is able to assert other specific statutory procedural preferences, it is in a relatively stronger negotiating position. ${ }^{120}$ The result is a denial of equality before and under the law and equal protection of the law, contrary to section 15 .

However, the very unenumerated status of alleged discrimination of this type underscores the onus on the plaintiff to establish the contravention. Demonstration of the distinction between persons who deal with Crown corporations and those who deal with similar private corporations may not be considered to raise a presumption of discrimination. ${ }^{121}$

There are, in fact, a number of problems in the way of successfully asserting s. 15 rights in these circumstances. First, s. 15 may confer rights only on individuals and not on corporations. The rights are given to "every individual", as opposed, for example, to "everyone" under ss. 7-10 and "any person" under s. 11. Lower court decisions that have considered this point, have tended to hold that s. 15(1) rights are not granted to corporations. ${ }^{122}$

A second problem is that there are strong indications that some variant of the U.S., "levels of scrutiny" approach will be followed. ${ }^{123}$ Whatever

117. See A. Bayefsky, "Defining Equality Rights" 1, 77-78. In A. Bayefsky and M. Eberts (eds.), Equality Rights and the Canadian Charter of Rights and Freedoms (1985). See Smith, Kline and French Laboratories Ltd. v. A-G Can. (1985) 24 D.L.R. (4th) 321 (F.C.T.D.); Re Blainey and Ontario Hockey Assn. (1985) 21 D.L.R. (4th) 599 (Ont. H.C.); rev'd (1986) 26 D.L.R. (4th) 728 (Ont. C.A.).

118. Operation Dismantle v. The Queen supra n. 72 at 517 (D.L.R.) per Wilson J.; Singh v. Minister of Employment and Immigration supra n. 64; Re Federal Republic of Germany and Rauca (1983) 145 D.L.R. (3d) 638, 658 (Ont. C.A.).

119. A. Bayefsky, supra n. 117 at 48-49; Smith, Kline and French Laboratories Ltd. v. A-G Can. supra n. 117.

120. Such as special limitation periods under Public Authorities Protection legislation, immunity from certain remedies such as injunctions, and immunity from disclosure under public interest privilege including sections 36.1 and 36.2 of the Canada Evidence Act, R.S.C. 1970, c. E-10, an. S.C. 1980-81-82 c. 111, s. 4. See E. Kirsch, The Legal and Institutional Environment of Canadian Crown Corporations, Economic Council of Canada Study, May $1,1985$.

121. Smith, Kline and French Laboratories Ltd. v. A-G Can. supra n. 117.

122. See Re Weinstein and Minister of Education for British Columbia (1985) 20 D.L.R. (4th) 609 (B.C.S.C.); Smith, Kline and French Laboratories Ltd. v. A-G Can. supra n. 117; Re Homemade Winecrafts (Canada) Ltd. and A.G. B.C. (1986) 26 D.L.R. (4th) 468 (B.C.S.C.); Surrey Credit Union v. Mendonca (1985) 67 B.C.L.R. 310 (B.C.S.C.).

123. A. Bayefsky, supra $n$. 117 at $52-59$ and 68 with particular reference to Justice Marshall's "sliding scale" approach to classification. 
categorization develops, the existence of enumerated grounds strongly suggests that non-listed grounds will be candidates for minimal scrutiny. ${ }^{124}$ This may mean that little short of arbitrary or capricious or unnecessary measures will suffice for s. 15 infringement. This "minimal scrutiny" was precisely the approach of Strayer J. in Smith, Kline and French Laboratories v. A.G. Can. ${ }^{125}$ where alleged discrimination was less favourable Patent Act treatment for inventors and patentees of medicine than for other inventors and patentees.

The U.S. experience suggests that this will be particularly so if these nonlisted grounds involve matters of an economic character. In fact, U.S. authorities show that laws and actions that can be characterized as pure economic regulation will be upheld in the absence of direct interference with fundamental rights or inherently suspect approaches. ${ }^{126}$ However, there is no compelling reason to simply adopt the U.S. approach, and there are enough differences between the social, political and economic fabrics of Canada and the U.S. to suggest caution. There is also the significant omission of property rights protection in the Charter. This suggests the possibility of legislative intention that economic rights be protected under various Charter provisions. It also suggests that courts are likely to avoid completely closing the door to protection of economic rights in the early and formative stages of Charter interpretation.

\section{CROWN IMMUNITY}

The "business position" discrimination suggested ultimately strikes hardest at the concept of Crown immunity itself. This doctrine is the source of the most serious discriminatory powers of commercial Crown corporations. In principle most Crown immunities based on statute or common law are subject to Charter protections. ${ }^{127}$ However, it is likely that courts will tread carefully in considering potential limitation of a doctrine that flows from the fundamental legal concept of the state in our legal system..$^{128}$

Individual cases of this kind of discrimination may be seen as private consequences of pursuit of high government policies. This is analogous to the private consequences of public regulatory systems. It will be recalled that the primary rationale for the Crown corporation concept is that it provides an indirect and subtle policy instrument for government. The view that section 15 discrimination based on privileges and immunities of Crown corporations will be difficult to establish is bolstered by the emergence in Canada of the doctrine of relative or restrictive sovereign immunity. ${ }^{129}$ This permits courts to adjust the scope of immunity for commercial Crown corporations without necessarily reaching Charter grounds.

124. Smith, Kline and French Laboratories Ltd. v. A-G Can. supra n. 117 at 368-369.

125. Supra n. 117.

126. City of New Orleans v. Dukes 427 U.S. 297 (1976) 96B S. Ct. 2513; L. Tribe, American Constitutional Law supra n. 96 at 996.

127. See D. Gibson, The Law of the Charter: General Principles supra n. 69 at 169.

128. See Law Reform Commission of Canada, The Legal Status of the Federal Administration Working Paper 40, 1985 at 49.

129. Supra pp. 24-25. 
Western Surety Co. v. Elk Valley Logging Ltd.; The Queen in Right of Alberta (Third Party) ${ }^{130}$ is instructive. The action was brought by a bonding company against sureties under a B.C. contractor's performance bond for a highway construction contract with the Government of Alberta, following default by the contractor and completion of the construction by the bonding company. When one of the sureties joined the Crown in right of Alberta as a third party in the action, Alberta applied to strike out the third party notice. The ground was that Alberta is a sovereign entity and consequently is immune from process of this kind. The surety denied that Crown immunity existed in these circumstances because the Crown was acting in a commercial capacity, and in the alternative asserted denial of her right to equal benefit under S. 15(1) of the Charter. The discrimination alleged was that the surety's British Columbia residence prevented her from claiming indemnity against Alberta in the action brought by the plaintiff bonding company in B.C. It was thus the combination of the surety's residence and the plaintiff's choice of situs of the action that produced discrimination.

It was held first, that while sovereign immunity may be relative or restrictive, it nevertheless protected Alberta because the province, in contracting for highway construction, was carrying out a government function rather than a commercial activity. The court then concluded that the surety's s. 15(1) rights were not violated because she was not without a remedy. In the event of the plaintiff's success in the action, the surety could then sue Alberta for indemnity in the Alberta courts.

The court's approach shows that the relative scope of sovereign immunity will be considered first. Even if the action is held to be protected by sovereign immunity, the further question will be whether there is nevertheless an adequate remedy. If not, as where action is absolutely barred by the immunity principle, then arguably there is infringement of $s$. 15. Section 1 balancing would then be crucial.

The onus will be on the Crown to establish that the immunity is "reasonable" and "demonstrably justified" in a free and democratic society. It must demonstrate that this is a case where, as Dickson, C.J.C. put it in $R$. v. Oakes, it is necessary to limit the right in circumstances where its exercise, "would be inimical to the realization of collective goals of fundamental importance". ${ }^{131}$ This involves two central criteria. First, the objective which the Charter infringing law or action is designed to serve must be of "sufficient importance to warrant overriding a constitutionally protected right or freedom. ${ }^{132}$ This involves a high standard related to concerns that are, "pressing and substantial" in a free and democratic society. Second, it must be shown that the means chosen are "proportional" ${ }^{33}$ in the sense of carefully designed to meet the particular objective, and without arbitrary, unfair or irrational features. They must be rationally connected to the objective. The means chosen must impair the

130. (1986) 31 D.L.R. 193 (B.C.S.C.).

131. R. v. Oakes supra n. 116 at 126 (S.C.C.).

132. R v. Big M. Drug Mart Ltd. [1985] I S.C.R. 295 at 352; 58 N.R. 81 quoted by Dickson C.J.C. in $R$. v. Oakes supra n. 132 at128-129.

133. R. v. Oakes supra n. 116 at 129. 
protected right as little as possible, and the proportionality test must be applied by weighing the effects of the limiting measures against the "sufficiently important" objective.

While the policy objective of a Crown corporation and the necessity for use of the Crown corporation instrument to achieve that objective must be considered, it is the particular immunity, operating in the specific circumstances that must be weighed in relation to the policy objective. It is possible that while Crown law principles of relative or restrictive immunity suggest that there is a public purpose to. which immunity applies, the immunity may nevertheless violate s. 15 and not be justifiable under s. 1 . This is because the immunity principles are based on the need to protect state sovereignty primarily in international relations and on the inappropriateness of judicial intervention in certain matters involving state revenues or property; but Charter rights have a different basis. The Charter aims at protection of individual rights and freedoms, and it is these that have been placed on the higher footing of constitutional guarantees.

This suggests that absolute immunity from judicial review for a commercial Crown corporation that functions in some respects as a Crown agent is unlikely to pass the initial "insufficient importance" test. It is even clearer when the standard adopted is that of concerns that are "pressing and substantial". There may, however, be an area of high government policy - for example, atomic energy policy, implemented through the means of Crown corporations such as Atomic Energy Canada Ltd., Eldorado Nuclear Ltd., and Uranium Canada Ltd. - that is readily seen to have state security and international relations implications. These considerations may be found to be "pressing and substantial".

However, focus would then shift to the proportionality criterion. Consider, for example, actions by the federal Crown corporation, Eldorado Nuclear Ltd. that result in discharge of contaminants from a uranium refinery into water, contrary to the relevant provincial environmental source.$^{134}$ If affected private landowners institute a private prosecution under the provincial offence provision, the immunity of the corporation from provincial statutes that do not bind the federal Crown may be asserted. ${ }^{135}$ It must then be asked whether this immunity is "carefully designed" to meet the requirements, including waste disposal requirements, inherent in the development and operation of nuclear technologies. Is it "arbirary"? A prosecution would be potentially

134. See R. v. Eldorado Nuclear Limited (1981) 121 D.L.R. (3d) 392 (Ont. Co. Ct.) in which the Crown corporation was held to be immune from prosecution under The Ontario Water Resources Act.

135. See The Queen in Right of Alberta v. Canadian Transport Commission [1978] 1 S.C.R. 61, (1977) 75 D.L.R. (3d) 257 per Laskin C.J.C. at 264-267 (D.L.R.); A.G. Que. and Keable v. A.G. Can. [1979] 1 S.C.R. 218, 244. The Law Reform Commission of Canada has suggested that this immunity (whether from provincial or federal statutes) is directly contrary to the principle of equality under the law established by section 15. See The Legal Status of the Federal Administration supra n. 128 at 15.

It is not clear however, whether this immunity is based on the application of the general presumption that the Crown is exempt from statutes to the Crown in all its capacities, or whether it is a constitutional immunity based essentially on the division of powers. If it is the latter, then it may be necessary to balance individual rights against the substantial constitutional value involved in maintenance of the integrity and rationality of the division of powers under the Constitution Act, 1867. 
available against a private developer; but the state interest, indeed the high government policy context, must not be forgotten. Is it irrational? Not necessarily, given the significant state security and international relations interests involved in nuclear technology and operations. Is it unfair? Again, not necessarily. A common law tort remedy may potentially lie against the Crown corporation. Also, procedural fairness protections may have been available to the landowners at the stage of regulatory approval by the Atomic Energy Control Board and by provincial land use planning and environmental authorities.

The second test of proportionality requires that impairment of protected rights be minimized. Short of outright prosection immunity, could state security concerns not be handled procedurally in a prosecution by such techniques as in camera proceedings and public interest information disclosure restrictions under The Canada Evidence Act? ${ }^{136}$ On balance, it is difficult to see how the proportionality test could be convincingly met; but the example shows that this result is far from certain.

Finally, even if the objective is of sufficient importance and the first two parts of the proportionality test are satisfied, the severity of the effects on individuals may be sufficient to deny justification. This bottom line was underlined by Chief Justice Dickson in $R$. v. Oakes. ${ }^{137}$ In the Eldorado Nuclear Ltd. example, it merely emphasizes a critical relationship that is also relevant to the other proportionality tests, namely whether the immunity as asserted in the circumstances, is reasonably necessary for attainment of the public purpose for which the Crown corporation was established.

\section{CONCLUSIONS}

The scope for judicial review of Crown corporation decisions is not wide. Yet there is a distinct window through which judicial review may affect Crown corporations, including those of an essentially commercial character. This "window" reflects two areas of principle - first, conventional judicial review of administrative action, and second, the Canadian Charter of Rights and Freedoms.

The Friedmann and Webb cases suggest that Crown corporation decisions that are taken in the implementation of government policies, apart from operational or internal corporate management matters, are subject to judicial review. Reviewable decisions are no less reviewable because they may also be characterized as business or commercial decisions. Grounds for review include procedural fairness and, to a lesser extent, scope and correctness of decisions. Fairness is likely to be most important because of the relatively wide scope provided by the "fairness doctrine". This is exemplified by the Webb case. Another factor is that the relative absence of a formal decision making process and guidelines of the kind usually adopted by boards and tribunals is likely to make scope and correctness review difficult. Finally, it may not be inappropriate to

136. Supra n. 120.

137. Supra n. 116 at 130. 
speculate that judicial restraint in cases that involve business or commercial matters, is likely to favour limited intervention based on procedural fairness grounds.

Potential for judicial review of Crown corporation decisions based on Charter grounds is much more problematic. It appears that the Charter does apply to many Crown corporation decisions. Application is likely to depend less on Crown agency designations than on a functional, but Charter rights-sensitive, approach. The governmental content of actions, and the extent to which the Charter rights in question may be eroded by non-application, are factors likely to govern Charter application.

Charter rights may affect Crown corporations in two ways. First, they may be asserted in a procedural sense, either to strike down statutory provisions that purport to remove or restrict conventional judicial review, or to provide an alternative basis for procedural fairness when conventional judicial review rights are uncertain. Second, Charter rights of affected persons may be enforced substantively to directly render certain actions by Crown corporations without force or effect.

The prospect of asserting section 7 rights against Crown corporations is limited because of the absence of a clear property protection. Lower court decisions to date also suggest a judicial reluctance to bring economic rights within the "liberty" and "security of the person" rights.

Section 15 may be more promising. In particular, it appears to be the major basis for an attack on statutory and common law immunities that may be raised by Crown corporations. Such immunities, including the Crown agent immunity from application of legislation, seem on their face to infringe section 15 rights. The next step, consideration of possible s. 1 limitation, will pitch the courts directly into the most difficult Crown corporation issue of all - assessment of the relative importance of the public purpose for which particular Crown corporations were established, and immunities conferred. 